\title{
SOIL ATTRIBUTES IN CONVENTIONAL TILLAGE OF Coffea arabica L.: A CASE STUDY
}

\author{
Raquel Pinheiro da Mota ${ }^{1}$ Risely Ferraz de Almeida ${ }^{2}$, Ernane Miranda Lemes ${ }^{3}$, Camilla Buiatti ${ }^{4}$, \\ Lettícia Alvarenga ${ }^{5}$, Mara Lúcia Martins Magela ${ }^{6}$, Reginaldo de Camargo ${ }^{7}$
}

(Received: May 25, 2017; accepted: November 06, 2017)

\begin{abstract}
Coffee production presents great economic and social importance. To increases coffee production and decreases the environmental impacts of its activity, it is necessary to know the soil attributes and their impacts on plant development. Therefore, due to the importance of the soil physical and chemical attributes, as well as the significance of coffee to Brazil, the objective of this study was to evaluate the physical and chemical attributes of an Oxisol planted with coffee conducted under conventional tillage system. For the purposes of analysis and interpretation of the data, the experiment was performed and interpreted in a completely randomized design, with the factorial $3 \times 2$, referring to three locations in the area of the coffee plantation (planting line, canopy projection, between planting lines) and two soil layers $(0-0.2 \mathrm{~m}$ and $0.2-0.4 \mathrm{~m})$, with four replications. It is concluded that no distinctions for soil porosity and total porosity was observed among soil locations, and that 'planting line' position showed superior concentrations of total organic carbon and mean geometric diameter of the soil aggregates.
\end{abstract}

Index terms: Coffee, soil aggregates, soil organic carbon, macroporosity, microporosity.

\section{ATRIBUTOS DO SOLO COM PLANTIO CONVENCIONAL DE Coffea arabica L.: UM ESTUDO DE CASO}

RESUMO: A produção de café (Coffea arabica) apresenta grande importância socioeconômica no Brasil. Para melhor desenvolvimento da cultura e redução de impactos ambientais, faz-se necessário conhecer os atributos do solo. Dada a importância dos atributos físicos e químicos do solo, bem como a posição de destaque do Estado de Minas Gerais como maior produtor de café do Brasil, o objetivo do estudo foi avaliar os atributos físicos e químicos de um Latossolo Vermelho textura argilosa em uso com café manejado em sistema de plantio convencional, na Região do Triângulo Mineiro. Para efeito de análise e interpretação da exploração dos dados, o experimento foi realizado e interpretado em esquema de delineamento inteiramente casualizado - DIC, com o fatorial 3 x 2, referente a três localizações na área do cafezal (tronco, saia e rua) e duas camadas $(0,0-0,2$ e $0,2-0,4 \mathrm{~m})$, com quatro repetições. Conclui-se que a posição do tronco do cafeeiro apresentou maiores concentrações de carbono orgânico total e diâmetro médio geométrico, enquanto que para macroporosidade e porosidade total não houve distinções entre os tratamentos.

Termos para indexação: Café, agregados do solo, carbono orgânico do solo, macroporosidade, microporosidade.

\section{INTRODUCTION}

Coffee production is of great economical importance to Brazil, both for job creation and for income profits to coffee farmers, helping to prevent the exodus from rural areas. The Brazilian states of Minas Gerais, São Paulo, Espírito Santo, Paraná, Bahia and Rondônia have the largest coffee production, prevailing the Coffea arabica specie (ORMOND; FAVERET FILHO, 2002). In addition to the socioeconomic importance, also should be give attention to soil attributes in coffee areas, which area part of the ecosystem and can significantly count for better coffee development and production.

Soil is a natural resource essential for human survival, and responsible for a high quality environment, as well as for the fauna and flora sanity (SHARMA et al., 2005). However, the inappropriate use, especially the adoption of conventional tillage systems of soil management (plowing and harrowing), has caused soil degradation such as the rupture of soil aggregates, soil compaction, fertility decline, fast organic matter oxidation and reduction of the quantity and diversity of soil microorganisms (MOURA, 2004; MILK et al., 2010).

The conventional tillage system contributes to soil and nature degradation because of the high levels of fertilizers and pesticides applied to the crop together with high superficial soil losses specially during rain (CASTELLINI et al., 2006; GÜNDOĞMUŞ, 2006).

\footnotetext{
1,3,4,6,7 Universidade Federal de Uberlândia/UFU - Instituto de Ciências Agrarias - Av Pará, 1720- Bairro Umuarama - Uberlândia - MG 38.408-100 - Cx. P 593 - raquel.agr@hotmail.com, ernanelemes@yahoo.com.br, camilla.buiatti@syngenta.com, maralumm@hotmail.com, rcamargo@ufu.br

${ }^{2}$ Universidade Estadual Paulista/UNESP - Via de Acesso Prof.Paulo Donato Castellane s/n, 14.884-900 - Jaboticabal - SP - rizely@gmail.com ${ }^{5}$ Centro Universitário do Triângulo - Av. Nicomedes Alves dos Santos, 4545 - Gávea - Uberlândia - MG - 38.411-106 letticia.alvarenga@syngenta.com
} 
Also, the tillage farming contributes to greenhouse effect through the increase of the carbon dioxide emissions into atmosphere (KALTSAS et al., 2007). The cultivation of Coffea spp.., using this system, occurs in most coffee areas of Brazil (PARTELLI et al., 2011),being necessary continuous observation of the soil physical and chemical attributes to reduce the impacts generated by this system.

The physical and chemical soil directly influence the development of crops (BURNS et al., 2006), and the analysis of these attributes are essential to the management strategies that confer an increase in agricultural productivity, especially in perennial crops, as in the case of coffee. Given the importance of the soil physical and chemical attributes to coffee and the damaging effects of soil conventional farming, that the objective of this study was to evaluate the physical and chemical attributes of an Oxisol planted with productive coffee in a soil tillage system.

\section{MATERIAL AND METHODS}

\subsection{Experimental area characterization}

The area chosen for this study is located at the coordinates $18^{\circ} 52^{\prime} 00^{\prime \prime} \mathrm{S}$ and $47^{\circ} 57^{\prime} 40^{\prime \prime} \mathrm{W}$, in the municipality of Indianópolis, Minas Gerais state, Brazil. The region has an average altitude of $804 \mathrm{~m}$ and climate of the type Aw characterized as tropical rainy season (JONES, 1986).

For the purposes of analysis and interpretation of data exploration, the experiment was performed and interpreted in a completely randomized design, with the factorial $3 \times 2$, referring to three locations in the area of coffee plantation (planting line, canopy projection, between planting lines) and two soil layers (0-0.2 and 0.2-0.4 m), with four replicates. Posteriorly, soil was classified as a dystrophic red clay texture with predominance of clay fraction ranging between 16 to 29\% (EMBRAPA, 1997). The chemical characterization (Soil water $\mathrm{pH}$; potassium- $\mathrm{K}^{+}$; magnesium- $\mathrm{Mg}^{+}$; calcium- $\mathrm{Ca}^{+2}$; aluminum- $\mathrm{Al}^{+3}$; and potential acidity- $\mathrm{H}+\mathrm{Al}$ ) was determined according to Tedesco et al. (1995). While, the phosphorus-P was determined using the Mehlich1 methodology following the Tedesco et al. (1995), and textural characterization according the methodologies recommended by Embrapa (1997).

\subsection{Coffee management}

The coffee (C. arabica $\mathrm{cv}$. Mundo Novo) planting was done in 2003 through conventional tillage with the use of plow and grid for the soil preparation $(0.2 \mathrm{~m})$. In this same year it was applied cattle manure at the planting time $\left(1 \mathrm{~kg}\right.$ plant $\left.^{-1}\right)$. Coffee plants were spaced $4 \times 0.7 \mathrm{~m}$ between planting lines and coffee plants, respectively. The irrigation system of the coffee area is based on the localized dripping system, which aims to save water, automation, efficiency and labor reducing.

The mineral fertilization was performed in the period from October to March every year, with the application of $350 \mathrm{~kg} \mathrm{ha}^{-1}$ of NPK 1801-20 (spreader), fertilization through irrigation and foliar fertilization for micronutrients supplementation. In order to control weeds it was performed manual weeding and the application of $3 \mathrm{~L} \mathrm{ha}^{-1}$ of glyphosate. Unproductive coffee branches were also removed to give great support structure of production, as described by Thomaziello (2013).

The coffee harvest was mechanized and done manually only for coffee plants where the machine could not reap the coffee beans. Straws, leaves and other crop residues were left over the soil. In the year 2013, there was an average productivity of 40 bags ha-1 $^{-1}$.

\subsection{Soil collection and analyzed variables}

The soil samples were collected in 2014 at the layers $0-0.2 \mathrm{~m}$ and $0.2-0.4 \mathrm{~m}$. To sample the soil it was used a hoe and a ruler to measure soil depth. Initially, it was removed the excess of organic matter on soil surface and subsequently the samples were dig out. The samples were sent to the soil laboratory properly packaged and labeled in plastic bags.

In the lab the soil samples were air dried and sieved $(<2 \mathrm{~mm}$ ) to obtaining the FSAD (fine soil air dried). The total nitrogen (TN) was determined according to the Kjeldahl method (BLACK, 1965), while the total organic carbon (TOC) was determined by the method of potassium dichromate oxidation in acidic medium. The carbon soluble in water (CSA) was extracted with deionized water (YEOMANS; BREMNER, 1988). The availability of macronutrients (N, P, K, $\mathrm{Ca}, \mathrm{Mg}, \mathrm{S})$ and micronutrients $(\mathrm{B}, \mathrm{Cl}, \mathrm{Cu}, \mathrm{Fe}, \mathrm{Mn}$, $\mathrm{Zn})$ were determined according to Tedesco et al. (1995), as well as the potential acidity $(\mathrm{H}+\mathrm{Al})$, aluminum $\left(\mathrm{Al}^{+3}\right)$ and the water $\mathrm{pH}\left(\mathrm{pH}-\mathrm{H}_{2} \mathrm{O}\right)$.

The determination of water dispersible clay (WDC) was done by the method of volumetric pipette according to the methodology described by Gee and Sao (1986) with the use of chemical dispersant (EMBRAPA,1997). 
TABLE1 - Physical and chemical characterization of two soil layers $0-0.2$ and $0.2-0.4 \mathrm{~m}$ in area with coffee cultivation. Indianópolis-MG.

\begin{tabular}{|c|c|c|c|c|c|c|c|c|c|c|}
\hline \multirow{3}{*}{$\begin{array}{l}\text { Soil } \\
\text { (m) }\end{array}$} & \multicolumn{10}{|c|}{ Chemical and physicalsoil attributes } \\
\hline & Sand & Silt & Clay & $\mathrm{pH}$ & $\mathrm{P}$ & $\mathrm{K}^{+}$ & $\mathrm{Mg}^{2+}$ & $\mathrm{Ca}^{2+}$ & $\mathrm{Al}^{3+}$ & $\mathrm{H}+\mathrm{Al}$ \\
\hline & \multicolumn{3}{|c|}{------gKg ${ }^{-1}(\mathrm{x} 100)------$} & $\left(\mathrm{H}_{2} \mathrm{O}\right)$ & \multicolumn{2}{|c|}{$---m g d m{ }^{-3}---$} & \multicolumn{4}{|c|}{ 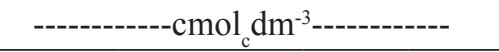 } \\
\hline $0-0.2$ & 1.2 & 1.0 & 7.4 & 5.23 & 13.06 & 0.53 & 0.7 & 1.50 & 0.2 & 3.33 \\
\hline $0.2-0.4$ & 1.7 & 2.4 & 5.9 & 5.1 & 28.07 & 0.65 & 0.9 & 1.83 & 0.2 & 4.60 \\
\hline
\end{tabular}

The collection of the undisturbed soil samples was performed on the same day of the collection of the deformed soil samples (for chemical and texture analysis). For collection of the undisturbed samples it was used an Uhland sampler and metal rings of Kopeck with sharpen edges. After the ring collection from ground and clean the excess of soil adhered, the non-sharpen ring size was covered with a silk paper and hold tight with a rubber band.

For determination of the geometric mean diameter (GMD) undisturbed soil samples were sieved with a sieve $(4 \mathrm{~mm})$ with the quantification of classes of aggregates through wet separation using aYoder equipment (Kemper and Rosenau, 1986). The soil aggregates were separated in class by sieves with $4,2,1,0.5$ and $0.25 \mathrm{~mm}$ meshes.

Also, it was determined with the soil sample in the volumetric rings (internal volume known): the soil density (SD), total porosity (TP), macropores (Ma) and micropores (Mi). The total porosity was calculated as described by Danielson and Sutherland (1986). The microporosity was determined by the content of water retained in the soil at the potential of $-0,006 \mathrm{MPa}$. The macroporosity was obtained by the difference between the total porosity and microporosity. The density of the soil expressed the relationship between the mass of dry soil and the volume of the sample, and is calculated with the mass of soil dried in an oven at $105^{\circ} \mathrm{C}$ for $24 \mathrm{~h}$ (BLAKE;HARTGE, 1986).

\subsection{Data processing and statistical analysis}

The variability of the studied properties was previously evaluated by means of descriptive statistics by calculating the mean values, standard deviations, minimum and maximum values observed. For the variables an analysis of variance (ANOVA) was performed, when the H0 was rejected was compared the measurements of treatments with test of Tukey test $(p<0.05)$.
Subsequently, the variables were submitted to analysis multivariate exploratory of grouping by hierarchical methods and main components. Previously to the statistical analyzes, the basic assumptions of ANOVA, normality of errors and homogeneity of variances were tested for all evaluated variables (data not shown).

For the principal components analysis (PCA), the variables: total organic carbon (TOC); $\mathrm{pH}-\mathrm{H}_{2} \mathrm{O}$; calcium $\left(\mathrm{Ca}^{+2}\right)$; magnesium $\left(\mathrm{Mg}^{+2}\right)$;

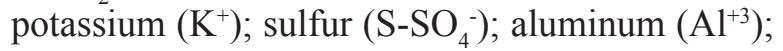
zinc $(\mathrm{Zn})$, manganese $(\mathrm{Mn})$; iron $(\mathrm{Fe})$; boron $(\mathrm{B})$; geometric mean diameter (GMD); microporosity (Mi) and macroporosity (Ma). Next, the set of variables were grouped according to their characteristics for better visualization of the relationship between the variables on the axes of coordinates. The new axis and the auto-vectors (new variables) called principal components (CP), are generated by linear combinations of the original variables constructed with the auto-values of the covariance matrix (HAIR et al., 2005; PIOVESAN, 2008). With the goal of obtaining a model more simple and parsimonious, we used the Kaiser criterion (1958), with auto-vectors above the unit. The analysis were conducted in STATISTICA 7.0 software (StatSoft. Inc., Tulsa, OK, USA).

\section{RESULTS AND DISCUSSION}

\subsection{Univariate analysis}

The levels of total organic carbon (TOC) presented a variation between 16.75 and $18.82 \mathrm{~g} \mathrm{~kg}^{-1}$, while the soluble carbon fraction obtained lower concentrations, ranging from 0.04 to $0.06 \mathrm{~g} \mathrm{~kg}^{-1}$ (Figure 1). The highest concentrations of TOC occurred in the 'planting line' location, considered significantly equal to that found at the 'canopy projection' position, and $16.53 \%$ higher than 'between line' position in the coffee plantation (Figure 1). 


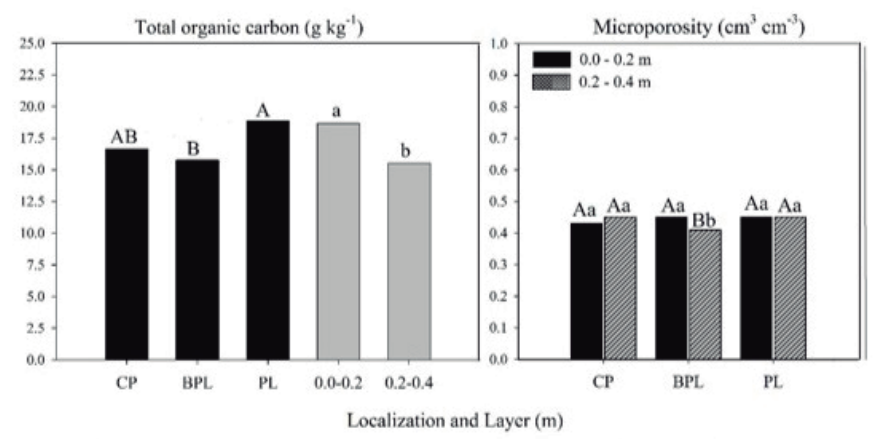

FIGURE 1 - Total organic carbon $\left(\mathrm{g} \mathrm{kg}^{-1}\right)$ and microporosity $\left(\mathrm{cm}^{3} \mathrm{~cm}^{-3}\right)$ located in the planting line (PL), canopy projection (CP), between planting lines (BPL) position of a coffee plantation in layers of $0-0.2$ and $0.2-0.4 \mathrm{~m}$.

The 'between planting line' position showed lower levels of TOC due to soil compaction by traffic of machines during the cultural treatments, such as fungicides and insecticides spraying, as well as the application of nutrients and weed control with the use of herbicides, which ends up as a result eliminating other green fertilizers that could cover ground, thus contributing to soil compaction and erosion over time. According to Araujo-Junior et al. (2011), this soil compaction is probably due to soil tillage systems, mechanization and the weed control that elevate the soil density, especially at $0-3 \mathrm{~cm}$ and $10-13 \mathrm{~cm}$ soil layers.

The volume of plant cover accumulated on soil can influence the levels of soil organic matter, favors the action of microorganisms and the humification process of the crop residues produced (MARTINS-NETO; MATSUMOTO, 2010). Among the effects of soil organic matter, what stands out is the stimulation of microorganisms diversity in the soil, due to nutrient cycling and energy for microorganisms activity (MOREIRA; CARNEIRO, 2004; COSTA et al., 2013). ROLDÁN et al. (2003) found that in soils with coverage $\leq$ at $33 \%$, the microbial biomass was reduced $\left(322 \mathrm{mg} \mathrm{kg}^{-1}\right)$ in relation to soils with $66 \%\left(426 \mathrm{mg} \mathrm{kg}^{-1}\right)$ and $100 \%\left(654 \mathrm{mg} \mathrm{kg}^{-1)}\right.$ surface coverage.

TP and Ma showed no differences between the locations in the coffee plantation, with variations of 0.54 to 0.53 and 0.08 to $0.1 \mathrm{~cm}^{3} \mathrm{~cm}^{-3}$, respectively (Table 2). The amount of Mi showed distinction between the positions (planting line, canopy projection, between planting lines), varying between 0.43 and $0.46 \mathrm{~cm}^{3} \mathrm{~cm}^{-3}$ (Figure 1).

High concentration of $\mathrm{Mi}$ is generally due to the compression caused by pressure exerted on the ground (SEIXAS; OLIVEIRA JÚNIOR, 2001), and therefore, a decrease in the amount of Ma is also observed (NETO, 2001; STRECK et al., 2004; SILVA et al., 2006; MENTGES et al., 2010). This condition affects soil water infiltration, root growth and the movement of solutes in the soil pore spaces (STONE et al., 2002). However, in our study we did not notice difference between the positions (Table 2).

The 'planting line' position presented high values of GMD, being $38.27 \%$ higher than 'between planting line' position (Figure 2). This result is due to a higher concentration of TOC in this position (Figure 1). In 'between planting line' position, the total porosity and aggregation are smaller and consequently the soil density is greater, because these physical attributes are inversely proportional. The passage of machinery in 'between planting line' position favors compression and contributes to reduce TOC. Richart et al. (2005) also identify that the increased use of machines induces soil compaction. The reduction of macro and microporosity after intense traffic of machines is also related to a significant increase in soil density (BALL et al., 1997).

The stability of soil aggregates, as assessed by the GMD, was greater in the soil less compacted ("planting line" position) in relation to "between planting line" position, and was similar between soil depths (BEUTLER et al., 2005).

\subsection{Multivariate analysis}

At PCA, there was the formation of a two-dimensional plane generated with first three main components: CP1 (44.95\%), CP2 (22.79\%) and CP3 $(9.12 \%)$ that account for $76.86 \%$ of the original information (Figure 3 and 4). This result is consistent with the criterion established by Sneath and Sokal (1973), in which the number of CP used in interpretation should be such that explain at least $70 \%$ of the total variance of the data, which is the case of this study. 
TABLE 2 - Descriptive statistical of the physical variables in an Oxisol cultivated with coffee positioned on (planting line, canopy projection, between planting lines),0 - $0.4 \mathrm{~m}$ layer.

\begin{tabular}{lccc}
\hline & WDC & Ma & TP \\
\hline Planting line & $0.01( \pm 0.01)$ & $0.08( \pm 0.04)$ & $0.54( \pm 0.03)$ \\
Canopy projection & $0.00( \pm 0.00)$ & $0.08( \pm 0.02)$ & $0.53( \pm 0.02)$ \\
Between planting lines & $0.00( \pm 0.00)$ & $0.10( \pm 0.05)$ & $0.53( \pm 0.03)$ \\
\hline Water dispersible clay $\left(\mathrm{WDC}, \mathrm{gKg}^{-1}\right) ;$ macropores-Ma $\left(\mathrm{cm}^{3} \mathrm{~cm}^{-3}\right) ;$ total porosity $\left(\mathrm{TP} \mathrm{cm}^{3} \mathrm{~cm}^{-3}\right)$. The variables, Ma, \\
WDC and TP were not significant by Tukey test at $(\mathrm{P}<0.05)$.
\end{tabular}

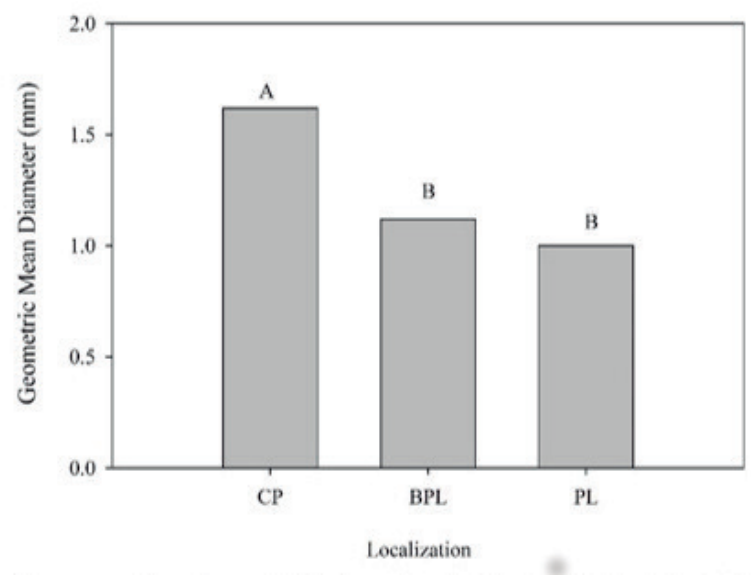

FIGURE 2 - Geometric mean diameter - DMG (mm) located in the planting line (PL), canopy projection (CP), between planting lines (BPL) position of a coffee plantation in layers of $0-0.2$ and $0.2-0.4 \mathrm{~m}$. At the figure, capital letters distinguish DMG for each position by Tukey test $(\mathrm{p}<0.05)$. CV: $29.81 \%$.

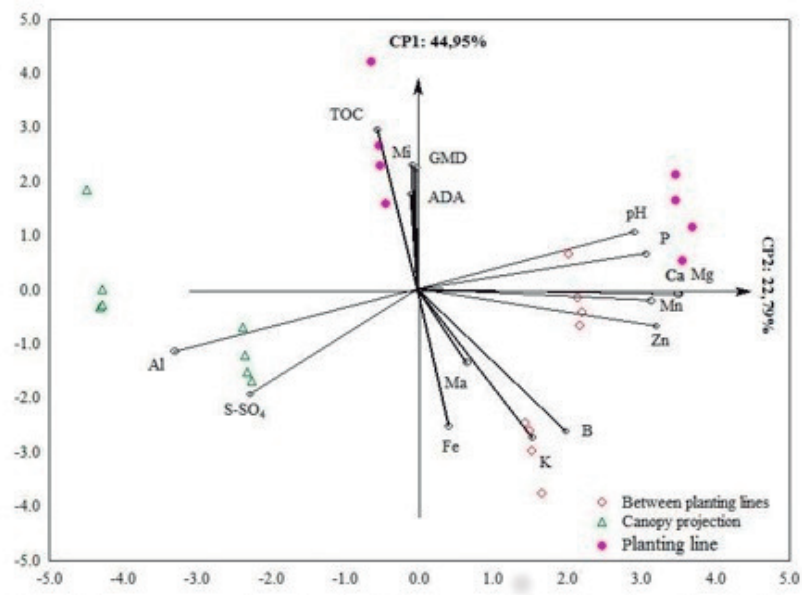

FIGURE 3 - Principal component analysis (PCA) of the CP1 and CP2 with the variables: total organic carbon (TOC); $\mathrm{pH}-\mathrm{H}_{2} \mathrm{O}$; calcium $\left(\mathrm{Ca}^{+2}\right)$; magnesium $\left(\mathrm{Mg}^{+2}\right)$; potassium $\left(\mathrm{K}^{+}\right)$; sulfur $\left(\mathrm{S}_{-} \mathrm{SO}_{4}\right)$; aluminum $\left(\mathrm{Al}^{+3}\right)$; zinc $(\mathrm{Zn})$, manganese (Mn); iron (Fe); boron (B); geometric mean diameter (GMD); microporosity (Mi), and macroporosity (Ma). 


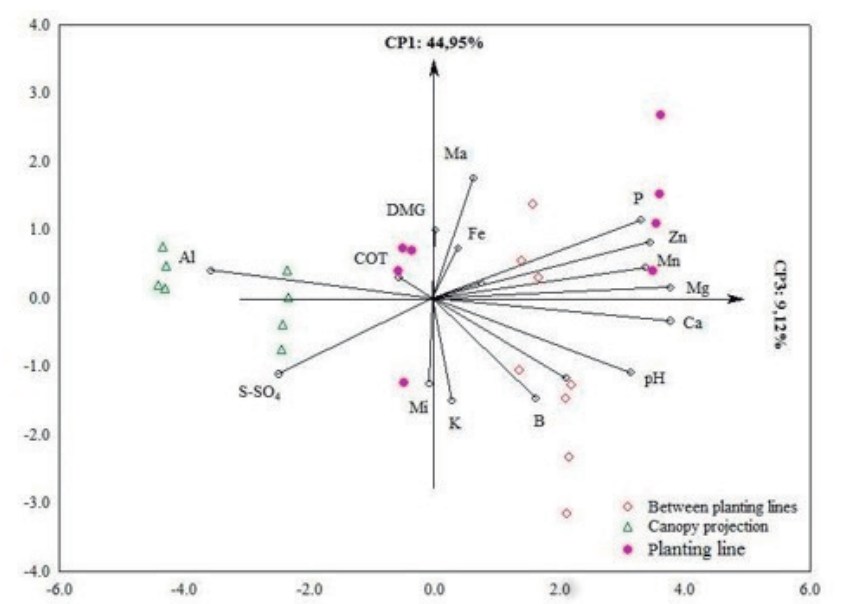

FIGURE 4 - Principal component analysis (PCA) of the CP1 and CP3 with the variables: total organic carbon (TOC); $\mathrm{pH}-\mathrm{H}_{2} \mathrm{O}$; calcium $\left(\mathrm{Ca}^{+2}\right)$; magnesium $\left(\mathrm{Mg}^{+2}\right)$; potassium $\left(\mathrm{K}^{+}\right)$; sulfur $\left(\mathrm{S}_{-} \mathrm{SO}_{4}\right)$; aluminum $\left(\mathrm{Al}^{+3}\right)$; zinc $(\mathrm{Zn})$, manganese (Mn); iron (Fe); boron (B); geometric mean diameter (GMD); microporosity (Mi), and macroporosity (Ma).

In CP1 were grouped the chemical attributes related to the availability of nutrients in order of importance from positive: $\mathrm{Ca}^{+2}(0.99), \mathrm{Mg}^{+2}(0.99)$, $\mathrm{Zn}(0.91), \mathrm{Mn}(0.88), \mathrm{P}(0.87), \mathrm{pH}-\mathrm{H}_{2} \mathrm{O}(0.82), \mathrm{B}$ $(0.56)$,to negative: $\mathrm{Al}^{+3}(-0.92)$ and $\mathrm{S}_{-} \mathrm{SO}_{4}^{-}(-0.63)$. In CP2 were grouped the physical and chemicals soil attributes in order of importance from positive: TOC (0.80), DMG (0.61), Mi (0.62), to negative $\mathrm{K}^{+}(-0.74)$; $\mathrm{B}(-0.71) ; \mathrm{Fe}(-0.68) ; \mathrm{S}^{-\mathrm{SO}_{4}^{-}}$(-0.52). In CP3 were also grouped physical attributes in order of importance Ma (-0.75) and Mi (0.70) (Table 3).

The soil concentration of $\mathrm{Ca}^{+2}$ and $\mathrm{Mg}^{+2}$ demonstrated in CP2, ranged 1.90 to 2.05 and

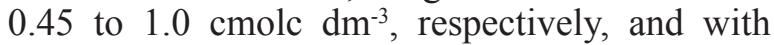
high positive correlation demonstrated in CP1 with overlapping vectors and associated with the 'planting line' position in coffee plantation (Figure 3). This characteristic is due to the fact that these elements are related to their chemical properties that are very similar, such as the ion charge and mobility in soil solution, favoring a competition between these elements by sites of adsorption in soil and the uptake by the root system (SALVADOR et al., 2011).

As a result, the presence in excess of one nutrient $\left(\mathrm{Ca}^{+2}\right.$ or $\left.\mathrm{Mg}^{+2}\right)$ can negatively affect the processes of adsorption and absorption of other (ORLANDO FILHO et al., 1996). El Salvador et al. (2011), observed that the relationship between levels of exchangeable $\mathrm{Ca}^{+2}$ and $\mathrm{Mg}^{+2}$ in the soil and quantities of $\mathrm{Ca}^{+2}$ and $\mathrm{Mg}^{+2}$ in leaf responds positively when the leaf content of these elements is $10 \mathrm{~g} \mathrm{~kg}^{-1}$, and exchangeable $\mathrm{Ca}^{+2}$ and $\mathrm{Mg}^{+2}$ in soil is of $1 \mathrm{cmolc} \mathrm{kg}^{-1}$. The same was also observed by Hernandez and Silveira (1998).
The inverse relationship of $\mathrm{Al}^{+3}$ with the remaining nutrients with positive charges and the $\mathrm{pH}-\mathrm{H}_{2} \mathrm{O}$ is related with the availability of charges in the soil, which showed a variation between

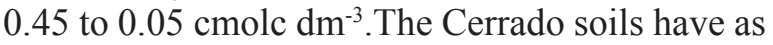
characteristics high levels of $\mathrm{Al}^{+3}$. In addition, these soils are naturally low in exchangeable bases to plants (LUZ et al., 2002; OLIVEIRA et al., 2005). However, lime and fertilizer applications reduce the amount of $\mathrm{Al}^{+3}$ retained in soil and replace it by cations $\left(\mathrm{Ca}^{+2}, \mathrm{Mg}^{+2}, \mathrm{~K}^{+}\right)$. Thus, when the soils from the Cerrado are included in the production process, is carried out the practice of liming as a form of correction (OLIVEIRA et al., 2005).

The soil $\mathrm{pH}$ presented a variation between 4.75 and 5.4 and with high correlation with the $\mathrm{P}$ availability in soil, which ranged from 5.9 to $34.75 \mathrm{mg} \mathrm{dm}^{-3}$ with the highest contents observed at the 'planting line' position. This is probable due to the low solubility of natural phosphates applied close to the "planting line' position. The natural phosphates are an effective source of Pespecially in soils with $\mathrm{pH}$ lower than 5.5 (OLIVEIRA et al., 2005).

The relationship of the soil physical attributes grouped in CP2 shows the positive relationship of the TOC and $\mathrm{Fe}$ in the formation of soil aggregates (DMG) (Table 3). As with the $\mathrm{K}$, a monovalent cation $(+)$, this correlation has been reversed. The TOC is directly related with DMG, because when occurs the rupture of soil aggregates it causes a destabilisation of organic matter making it susceptible to decomposition by microorganisms (SOLLINS et al., 1996; CORAZZA et al., 1999). 
TABLE 3 - Correlation coefficient of main components for the variables: water dispersible clay (WDC); total organic carbon (TOC); geometric mean diameter (GMD); macroporosity (Ma); microporosity (Mi); $\mathrm{pH}_{-} \mathrm{H}_{2} \mathrm{O}$; phosphorus $(\mathrm{P})$, potassium $\left(\mathrm{K}^{+}\right)$; calcium $\left(\mathrm{Ca}^{+2}\right)$; magnesium $\left(\mathrm{Mg}^{+2}\right)$; boron $(\mathrm{B})$; iron $(\mathrm{Fe})$; manganese $(\mathrm{Mn})$; zinc $(\mathrm{Zn})$; sulfur $\left(\mathrm{S}_{-} \mathrm{SO}_{4}^{-}\right)$, and aluminum $\left(\mathrm{Al}^{+3}\right)$.

\begin{tabular}{|c|c|c|c|}
\hline & CP1 (44.95\%) & CP2 (22.79\%) & CP3 (9.12\%) \\
\hline WDC & -0.02 & 0.47 & -0.16 \\
\hline TOC & -0.15 & 0.80 & -0.32 \\
\hline DMG & 0.00 & 0.61 & -0.46 \\
\hline $\mathrm{Ma}$ & 0.19 & -0.37 & -0.75 \\
\hline Mi & -0.02 & 0.62 & 0.70 \\
\hline $\mathrm{pH}-\mathrm{H}_{2} \mathrm{O}$ & 0.82 & 0.29 & 0.20 \\
\hline $\mathrm{P}$ & 0.87 & 0.18 & -0.04 \\
\hline $\mathrm{K}^{+}$ & 0.44 & -0.74 & 0.12 \\
\hline $\mathrm{Ca}^{+2}$ & 0.99 & -0.02 & 0.10 \\
\hline $\mathrm{Mg}^{+2}$ & 0.99 & -0.02 & -0.05 \\
\hline B & 0.56 & -0.71 & 0.12 \\
\hline $\mathrm{Fe}$ & 0.12 & -0.68 & 0.12 \\
\hline $\mathrm{Mn}$ & 0.88 & -0.06 & -0.30 \\
\hline $\mathrm{Zn}$ & 0.91 & -0.18 & -0.08 \\
\hline $\mathrm{S}-\mathrm{SO}_{4}^{-}$ & -0.63 & -0.52 & -0.12 \\
\hline $\mathrm{Al}^{+3}$ & -0.92 & -0.31 & -0.03 \\
\hline
\end{tabular}

*Value refers to the percentage of the variability of the original set of data retained by the respective main components. Correlations in bold $(\mathrm{P}>0.5$ in absolute value) were considered in the interpretation of the main component highly significant (COELHO, 2003).

Thus, the decrease in soil organic matter, especially in soils with low activity clays, cause further declines in the aggregate stability, which demonstrates that both parameters are related (CARTER et al., 1994; FELLER; TOME, 1997; FIELDS et al., 1997).

The soil aggregates are formed by physical forces that act in the process of wetting and drying, freezing and thawing, by compression caused by the root system and by the interactions of minerals and organic compounds from soil. However, for these processes occur is crucial the presence of flocculants and cementing agents, such as iron and aluminum oxides, plant roots and organic matter (BAYER; MIELNICZUK, 2008). Soil organic matter is essential for the stabilization of soil structure because it provides a large amount of radicals that can interact with the surface of the soil minerals and start the formation of soil aggregates (BAYER; MIELNICZUK, 2008).

It was observed that the action of the soil oxides in the process of aggregation is dependent upon both of their concentration and type, as well as the levels of organic carbon present in the soil
(FERREIRA et al., 2007). For the same authors occurred only correlation between the levels of organic carbon in the soil and the distribution of aggregates, and between the levels of organic carbon in the soil and the contents of organic carbon in aggregates.

In relation to $\mathrm{K}$, the correlation was reversed, because this chemical element promotes the dispersion of soil particles, causing the rupture of aggregates. This dispersion happens when flocculating cations $\left(\mathrm{Al}^{3+}, \mathrm{Ca}^{2+}, \mathrm{Mg}^{2+}\right)$ that often saturates clays, are replace by monovalent cations of higher hydrate ionic radius (MAURI et al., 2011). The inverse relationship of porosity (Ma and Mi) has been put together in CP3. The reductions in $\mathrm{Ma}$ in a compacted soil are usually followed by additions in Mi (GENROJUNIOR, 2002; SECCO et al., 2004).

\section{CONCLUSIONS}

The highest concentrations of total organic carbon occur in the 'planting line' of the coffee plantation. The 'planting line' location presents 
higher mean geometric diameter, with additions of $38.27 \%$, compared with 'between planting lines' location.

The porosity and total porosity show no distinctions among the three locations evaluated (planting line, canopy projection, between planting lines) in the coffee plantation. The microporosity is low at the 'between planting line' position probably due to machinery traffic to coffee cropping activities.

In accordance with the principal components analysis there is the formation of three groups that account for $76.86 \%$ of the variability of the original information found here.

\section{ACKNOWLEDGEMENT}

To the Fundação de Amparo à Pesquisa do Estado de Minas Gerais (FAPEMIG) and the Coordenação de Aperfeiçoamento de Pessoal de Nível Superior (CAPES) for their support and incentive for research.

\section{REFERENCES}

ANTUNES,F.Z. Caracterização climática do estado de Minas Gerais. Informe Agropecuário, Belo Horizonte, v. 12, n.138, p.9-13, 1986.

ARAUJO-JUNIOR, C.F. et al. Capacidade de suporte de carga e umidade crítica de um Latossolo induzida por diferentes manejos. Revista Brasileira de Ciência do Solo, Viçosa, v.35, n.1, p.115-131, 2011.

BALL, B.C. et al. Soil structural quality, compaction and land management. European Journal of Soil Science, Oxford, v.48, n.4, p.593-601, July/Aug. 1997.

BAVER, L.D. GARDNER, W.H.; GARDNER, W.R. Soil physics. 4th. New York, John Wiley, 1972. 498p.

BAYER, C. MIELNICZUK, J. Dinâmica e função da matéria orgânica. In: SANTOS, G.A. et al. eds. Fundamentos da Matéria orgânica do solo: ecossistemas tropicais e subtropicais. 2.ed. Porto Alegre, Genesis, 2008. p.7-16.

BEUTLER, A.N. et al. Efeito da compactação do solo na estabilidade de agregados e no conteúdo gravimétrico de água. Acta Sci. Agron, Maringá, v.27, n.2, p.193198, abr/jun. 2005.

BLAKE, G. R.; HARTGE, K.H. Bulk density. In: KLUTE, A. (Ed.). Methods of soil analisys:physical and mineralogical methods. Madison, American Society of Agronomy, 1986. p. 363-375.
BLACK, C.A. (Ed.). Methods of soil analysis. 2nd. Madison: American Society of Agronomy, 1965.

CAMPOS, B.C. et al. Estabilidade estrutural de um Latossolo Vermelho-Escuro distrófico após sete anos de rotação de culturas e sistemas de manejo de solo. Revista Brasileira de Ciência do Solo, Viçosa, 121126,1995 .

CARTER, M.R.; KUNELIUS, H.T.; ANGERS, D.A. Soil structure and organic matter fractions under perennial grasses. Soil Science Society of America Journal, Centralia, v. 58, n.4, p. 1194-1199, Feb. 1994.

CASTELLINI, C. et al. Sustainability of poultry production using the emergy approach: Comparison of conventional and organic rearing systems. Agriculture, Ecosystems and Environment, v. 114, n.343-350, June. 2006.

COELHO, A. M. Agricultura de precisão: manejo da variabilidade espacial e temporal dos solos e das culturas. In: CURI, N. et al. Tópicos em ciência do solo.Viçosa: Sociedade Brasileira de Ciência do Solo, 2003. v.3, p.259-290.

CORAZZA,E.J. et al. Comportamento de diferentes sistemas de manejo como fonte ou depósito de carbono em relação à vegetação de cerrado. Revista Brasileira de Ciência do Solo, Viçosa, v. 23, n. 2, p. 425-432,Apr/ June.1999

COSTA, E.M.; SILVA, H.F.; RIBEIRO, P.R.A. Matéria orgânica do solo e o seu papel na manutenção e produtividade dos sistemas agrícolas. Enciclopédia Biosfera, Goiânia, v.9, n.17; p.1842-1860, 2013.

DANIELSON, R.E.; SUTHERLAND, P.L. Porosity. In: KLUTE, A. (Ed.).Methods of soil analisys: physical and mineralogical methods. Madison, American Society of Agronomy, 1986.

EMPRESA BRASILEIRA DE PESQUISA AGROPECUÁRIA-EMBRAPA. Centro Nacional de Pesquisa de Solos. Manual de métodos de análise de solo. 2.ed. Rio de Janeiro, 1997. 212p.

FELLER, C.; BEARE, M.H. Physical control of soil organic matter dynamics in the tropics. Geoderma, v. 79, n. 1-4, p. 69-116, Sept. 1997.

FERREIRA, F. P.et al. Carbono orgânico, óxidos de ferro e distribuição de agregados em dois solos derivados de basalto no Rio Grande do Sul - Brasil. Ciência Rural, Santa Maria, v.37, n.2, p. 381-388, mar/abr.2007. 
FILHO, J.O.O. et al. Relações K, Ca e Mg de solo areia quartzosa e produtividade da cana-de-açúcar. STAB: Açúcar, Álcool e Subprodutos, Piracicaba, v.14, n.5, p.13-17, set/out. 1996.

GÜNDOĞMUŞ, E. Energy use on organic farming: A comparative analysis on organic versus conventional apricot production on small holdings in Turkey. Energy Conversion and Management, v. 47, n. 1819, p. 3351-3359, Nov. 2006.

GEE, G.W.; BAUDER, J.W. Particle-Size Analysis. In: KLUTE, A. (Ed.).Methods of soil analysis: Physical and mineralogical. Madison, American Society of Agronomy, 1986. p.383-411.

HAIR, J.F. et al. Análise multivariada de dados. Tradução: Adonai Schlup Sant'Anna e Anselmo Chaves Neto. 5.ed. Porto Alegre: Bookman, 2005, 600p.

HERNANDEZ, R.J. M.; SILVEIRA, R.I. Efeitos da saturação por bases, relações $\mathrm{Ca}: \mathrm{Mg}$ no solo e níveis de fósforo sobre a produção de material seco e nutrição mineral do milho (Zeamays L.). Scientia Agricola, Piracicaba, v.55, n.1, p.79-85, jan/abr. 1998.

JUNIOR, S.A. G. Alteração da compactação do solo com o uso de rotação de culturas no sistema plantio direto. 2002. 90p. (Tese de Mestrado). Universidade Federal de Santa Maria, Santa Maria, 2002.

KAISER, H. F. The varimax criterion for analytic rotation in factor analysis. Psychometrika, v. 23, n. 3. p. $187-200,1958$.

KALTSAS, A.M. et al. Energy budget in organic and conventional olive groves. Agriculture, Ecosystems and Environment, v.122, n. 2, p.243-251, 2007.

KEMPER, W.D.; ROSENAU, R.C. Aggregate stability and size distribution. In: KLUTE, A. ed. Methods of soil analysis. 2nd ed. Madison, American Society of Agronomy, Soil Science Society of America, 1986, p. 425-441.

LEITE, L.F.C. et al. Soil organic carbon and biological indicators in an Acrisol under tillage systems and organic management in north-eastern Brazil. Australian Journal of Soil Research, v.48, p.258265, 2010.

LUZ, M.J. DAS.; FERREIRA, G.B.; BEZERRA, J.R.C. Adubação e Correção do Solo: Procedimentos a Serem Adotados em Funçãodos Resultados da Análise do Solo. Circular Técnica, Campina Grande, p.1-32, out. 2002.
MARTINS-NETO, F.L.; MATSUMOTO, S.N. Qualidade do solo e nutrição de plantas em sistemas de produção de café (Coffeaarabica L.). Coffee Science, Lavras, v.5, n.3, p.206-213, set/dez. 2010.

MAURI, J. et al. Dispersantes químicos na análise granulométrica de latossolos. Revista Brasileira de Ciência do Solo, Viçosa, v.35, n.4, p.1277-1284, jul/ ago.2011.

MENTGES, M.I. et al. Propriedades físico-hídricas do solo e demanda energética de haste escarificadora em Argissolo compactado. Pesquisa Agropecuária Brasileira, Brasília, v.45, n.3, p.315-321, mar. 2010.

MOREIRA, A.; MALAVOLTA, E. Dinâmica da matéria orgânica e da biomassa microbiana em solo submetido a diferentes sistemas de manejo na Amazônia Ocidental. Pesquisa Agropecuária Brasileira, Brasília, v.39, n. 11, p.1103-1110, nov. 2004.

MOURA, E.G. Agroambientes de transição avaliados numa perspectiva da agricultura familiar. In: Moura, E.G. (Ed.). Agroambientes de transição entre o trópico úmido e o semi-árido do Brasil. São Luís: UEMA, 2004. cap.1, p.15-51.

NETO, P.C. Desenvolvimento e avaliação de equipamentos e metodologia para determinação de parâmetros físicos do solo relacionados a dias trabalháveis com máquinas agrícolas. 2001. Tese (Doutorado) -Faculdade de Ciências Agronômicas da UNESP, São Paulo, 2001.

OLIVEIRA, I.P. et al. Considerações sobre a acidez dos solos de Cerrado. Revista Eletrônica Faculdade Montes Belos, Goiás, v.1, n.1, p.01-12, 2005.

ORMOND, J.G.P; PAULA, S.R.L; FAVERET FILHO, P. Café: (Re) Conquista dos Mercados. Campinas, 2002.

PARTELLI, F.L.; et al. Perfil socioeconômico dos produtores de café orgânico do norte do Estado do Espírito Santo- satisfação com a atividade e razões de adesão à certificação. Revista Ceres, Viçosa, v. 53, n. 305 , p. 55-64,2006.

PIOVESAN, P.; ARAÚJO, L.B.; DEANDDIAS, C.T.S. Validação cruzada com correção de autovalores e regressão isotônica nos modelos de efeitos principais aditivos e interação multiplicativa. Ciência Rural, Santa Maria, v.39, n.1, p.1018-1023, jan/fev. 2008. 
RICHART, A. et al. Compactação do solo: causas e efeitos. Semina: Ciências Agrárias, Londrina, v.26, n.3, p.321-344, jul/set.2005.

ROLDÁN, A. et al. No-tillage, crop residue additions, and legume cover cropping effects on soil quality characteristics under maize inpatzcuaro watershed (mexico). Soil and Tillage Research, v.72, n.1, p.6573, 2003.

SALVADOR, J.T.; CARVALHO, T.C.; LUCCHESI, L. A.C. Relações cálcio e magnésio presentes no solo e teores foliares de macronutrientes. Revista Acadêmica: Ciências Agrárias e Ambientais, Curitiba, v.9, n.1, p.27-32, 2011.

SECCO, D. et al. Produtividade de soja e propriedades físicas de um Latossolo submetido a sistemas de manejo e compactação. Revista Brasileira Ciência do Solo, Viçosa, v. 28, n. 5, p. 797-804, set/out. 2004.

SEIXAS, F.; JÚNIOR, E.D. O. Compactação do solo devido ao tráfego de máquinas de colheita de madeira. Scientia Forestalis, Piracicaba, n.60, p.7387, dez.2001.

SHARMA, K.L. et al. Long-term soil management effects on cropyields and soil quality in a dryland Alfisol. Soil and Tillage Research, v.83, n.2, p.246259, Sept. 2005.

SIQUEIRA, H.M.; SOUZA, P.M.; PONCIANO, N.J. Café convencional versus café orgânico: perspectivas de sustentabilidade socioeconômica dos agricultores familiares do Espírito Santo. Revista Ceres, Viçosa, v.58, n.2, p.155-160, mar/abr, 2011.

SIMÕES, W.L. et al. Variabilidade espacial de atributos físicos de um LatossoloVermelho distroférrico submetido a diferentes manejos. Revista Brasileira Ciência do Solo, Viçosa, v. 30, n. 6, p. 1061-1068, nov/dez. 2006.
SNEATH, P.H.A; SOKAL, R.R. Numeric taxonomy: theprinciples and practice of numerical classification. San Francisco: W.H. Freeman, 1973.573p.

SOLLINS, P.; HOMMAN, P.; CALDWELL, B.A. Stabilization and destabilization of soil organic matter: mechanisms and controls. Geoderma, v.74, n. 1-2, p. 65-105, Nov. 1996.

STONE, L.F.; GUIMARÃES, C.M.; MOREIRA, J.A.A. Compactação do solo na cultura do feijoeiro. I. efeitos nas propriedades físico-hídricas do solo. Revista Brasileira de Engenharia Agrícola e Ambiental, Campina Grande, v.6, n.2, p.207-212, maio/ago. 2002.

STRECK, C.A. et al. Modificações em propriedades físicas com a compactação do solo causada pelo tráfego induzido de um trator em plantio direto. Ciência Rural, Santa Maria, v.34, n.3, p.755-760, 2004.

THOMAZIELLO, R.A. Uso da poda no cafeeiro: por que, quando e tipos utilizados. Revista visão agrícola, Piracicaba, v.1, n.12, p. 33-36, 2013.

TEDESCO, M.J. et al. Análise de solo, plantas e outros materiais. 2.ed. PortoAlegre: UFRGS, 1995.174p.

VIVIANI, C.A. et al. Disponibilidade de fósforo em dois Latossolos e Argilosos e seu acúmulo em plantas de soja, em função do aumento do pH. Ciência e Agrotecnologia, Lavras, v.34, n.1, p.61-67,2010.

YEOMANS, J.C.; BREMNERJ.M. A rapid and precise method four routine determination of organic carbon in soil. Communications in soil science and plant analysis, v.19, n. 13, p.1467-1476,1988. 